\title{
Nutritional and antioxidant profiles of pumpkin (Cucurbita pepo Linn.) immature and mature fruits as influenced by NPK fertilizer
}

\author{
F.M. Oloyede ${ }^{\mathrm{a}, *}$, G.O. Agbaje ${ }^{\mathrm{a}}$, E.M. Obuotor ${ }^{\mathrm{b}}$, I.O. Obisesan $^{\mathrm{a}}$ \\ ${ }^{a}$ Department of Crop Production and Protection, Obafemi Awolowo University, Ile-Ife, Nigeria \\ ${ }^{\mathrm{b}}$ Department of Biochemistry, Obafemi Awolowo University, Ile-Ife, Nigeria
}

\section{A R T I C L E I N F O}

\section{Article history:}

Received 21 December 2011

Received in revised form 2 April 2012

Accepted 23 April 2012

Available online 30 April 2012

\section{Keywords:}

Antioxidant

Fertilizer

Fruits

Proximate

Pumpkin

\begin{abstract}
A B S T R A C T
This study evaluated the influence of NPK fertilizer on protein, fibre, ash, fat, carbohydrate, antioxidant activities and antioxidant phenolic compounds in immature and mature fruits of pumpkin. The treatment consisted of six NPK levels $(0,50,100,150,200$ and $250 \mathrm{~kg} / \mathrm{ha}$ ), and was replicated six times in a randomized complete block design (RCBD). Proximate analysis and antioxidant assays were done using standard analytical methods. At control and lower NPK rates, the proximate compositions and antioxidant profile of pumpkin fruits decreased with increasing NPK fertilizer. Between the control and the highest fertilizer rate, proximate compositions decreased by $7-62 \%$ while the antioxidant profile decreased by $13-79 \%$ for both immature and mature fruits. Across all the measured parameters, mature fruit had higher proximate contents and higher antioxidant concentrations. For the high health value of pumpkin fruits to be maintained, little or no NPK fertilizer should be applied.
\end{abstract}

(c) 2012 Elsevier Ltd. All rights reserved.

\section{Introduction}

Fruits and vegetables are naturally rich in nutrients and antioxidants. Biochemical and in vitro studies of antioxidants in fruit and vegetables have indicated that they can provide protection against free radical damage. Free radicals, involved in many degenerative diseases of ageing and health hazards, are destroyed by the relatively high antioxidant concentrations in fruit and vegetables (Ames, Shigenaga, \& Hagen, 1993; Rice-Evans \& Miller, 1995).

Pumpkin, a member of the Cucurbitaceae family, is one of the largest families in the vegetable kingdom, consisting of largest number of edible plant species (Manjunath Prasad, Ashok, Vyakaranahal, Nadaf, \& Hosamani, 2008). Pumpkin fruits are extensively used as vegetable, both at immature and mature stages. The immature fruits, called courgettes, are eaten as a vegetable, boiled, fried or stuffed. Mature fruits, called pumpkin, are used peeled and cooked or prepared as pumpkin pie. In west Africa, the fruits are used in soup. Gem squashes, small globular fruits popular in southern Africa, are cooked whole or cut in half, and their flesh is scooped out and eaten (Messiaen \& Fagbayide, 2004). In the Middle East, nearly mature fruits of 'Causa' are stuffed with meat and other ingredients, followed by baking. Native Americans dried strips of squash flesh in the sun for preservation. Today, summer squash is usually cooked by boiling or frying, and winter squash by baking, boiling or microwaving (Robinson \& Decker-Walters,

\footnotetext{
* Corresponding author. Tel.: +234 7069766796.

E-mail address: funmilayooloyede@yahoo.co.uk (F.M. Oloyede).
}

1997). In Africa, the fruit pulp is used as a poultice to treat burns and inflammations and as a cooling compress to treat headache and neuralgia; it has also been applied to tumours (Messiaen \& Fagbayide, 2004).

In Nigeria, immature pumpkin fruits, called "kundu" in the south west, are consumed steamed in combination with the pumpkin young shoots called "Gboro". The mature fruits are consumed fresh or dried and added to soups. The immature fruit, at 14 days after fruit formation, contains between $75 \%$ and $85 \%$ water and weighs $120-400 \mathrm{~g}$ per fruit, while the water content of mature fruit has $75-80 \%$ and weighs between 1 and $2.5 \mathrm{~kg}$ per fruit.

In modern agriculture, chemical fertilizers constitute the major portion of total cost of crop production. The problem of soil limited availability and low fertility is solved, partially or completely, by using inorganic fertilizer to enhance crop productivity. This practice also has effect on the chemical composition of crops grown in such soils. This study investigated the effect of NPK 15:15:15 compound fertilizer on the proximate contents, antioxidant activities and phenolic compounds of pumpkin immature and mature fruits. NPK $15: 15: 15$ compound fertilizer was chosen because it is the most available fertilizer and most commonly used by the farmers.

\section{Material and methods}

\subsection{Field study}

Field study was conducted at the Teaching and Research Farm, Obafemi Awolowo Univerity, Ile-Ife, Nigeria, for 2 seasons in 2010. 
Pumpkin fruits were raised from seeds in a randomized complete block design, consisting of six rates of NPK 15:15:15 fertilizer at $0,50,100,150,200,250 \mathrm{~kg} / \mathrm{ha}$ with six replications of $10 \times 12 \mathrm{~m}$ plot size. Immature (14-day old) fruits ("kundu") were harvested from all the plots to form six composite samples. The samples were dried at $70^{\circ} \mathrm{C}$ for $24 \mathrm{~h}$, milled and kept in the refrigerator prior to analysis. At harvest, mature (40-day old) fruits of pumpkin from different plots were also oven-dried at $70{ }^{\circ} \mathrm{C}$ for $24 \mathrm{~h}$. The composite samples for the six treatments were also milled and stored in the refrigerator.

\subsection{Laboratory analyses}

Five grammes each of the composite samples were extracted (cold extraction, i.e. extraction not involving heat), for $24 \mathrm{~h}$, using $80 \%$ methanol. The crude extract was obtained by evaporation of the methanol-soluble extract to dryness in a rotary evaporator at $45^{\circ} \mathrm{C}$. The antioxidant activities or hydrogen-donating or radicalscavenging of the extract was determined using the stable radical $\mathrm{DPPH}^{\cdot}$ (2, 2-diphenyl-2-picrylhydrazyl hydrate) according to the method described by Brand-Williams, Cuvelier, \& Berset (1995). $\mathrm{DPPH}^{\cdot}$ reacts with an antioxidant compound which can donate hydrogen, it is reduced. The change in colour from deep violet to light yellow was measured spectrophotometrically at $517 \mathrm{~nm}$. Total phenol content was determined by the method of Singleton and Rossi (1965), using the Folin-Ciocalteau reagent in alkaline medium. Total flavonoid content was determined using the $\mathrm{AlCl}_{3}$ method, as described by Lamaison \& Carnet, 1990. The proanthocyanidin content was determined by a modified method of Porter, Hristch, and Chan (1986), using the $\mathrm{AlCl}_{3} /$ Butan - 1-0 1 assay method. The total anthocyanin content of the test samples was determined using the pH differential method of Fuleki and Francis (1968), as described by Guisti (2001). Crude protein, carbohydrate, ash, crude fibre, ether extract (fat) and moisture contents were determined using the routine chemical analytical methods of the AOAC (1995).

\subsection{Statistical analysis}

All data were subjected to combined analysis of variance SAS (2003). Means squares, where significantly different for NPK levels were separated using the Duncan multiple range test (DMRT) at 5\% level of probability. Least significant difference (LSD) and regression curves were used to compare the nutritional and antioxidant profiles of pumpkin fruits at different maturity stages.

\section{Results}

The protein, fat, ash, crude fibre and carbohydrate in pumpkin young and mature fruits were generally significantly influenced by fertilizer, the values decreased with increasing fertilizer. Fertilizer influence showed that proximate values of protein, fat, ash and crude fibre in pumpkin young and mature fruits were similar at 0,50 and $100 \mathrm{~kg} \mathrm{NPK} / \mathrm{ha}$. The nutrient values were reduced significantly when compared to the control from the application of $150 \mathrm{~kg} / \mathrm{ha}$ of NPK and this continued to the highest fertilizer rate ( $250 \mathrm{~kg} \mathrm{NPK} / \mathrm{ha}$ ). The carbohydrate result contrasted with the others. The values increased with increased fertilizer rates. Carbohydrate content in pumpkin young and mature fruits was highest with the application of 200 and $250 \mathrm{~kg} / \mathrm{ha}$ and lowest in 0 and $50 \mathrm{~kg} /$ ha (Figs. 1-5).

In comparison, at $0-150 \mathrm{~kg} /$ ha fertilizer application, the protein content of the mature fruit was significantly $(p=0.05)$ higher than that of young fruit, while the fat content was only significantly higher at $250 \mathrm{~kg} / \mathrm{ha}$ (Figs. 1 and 2). The ash content, which is an index of the mineral content, was significantly higher also in the

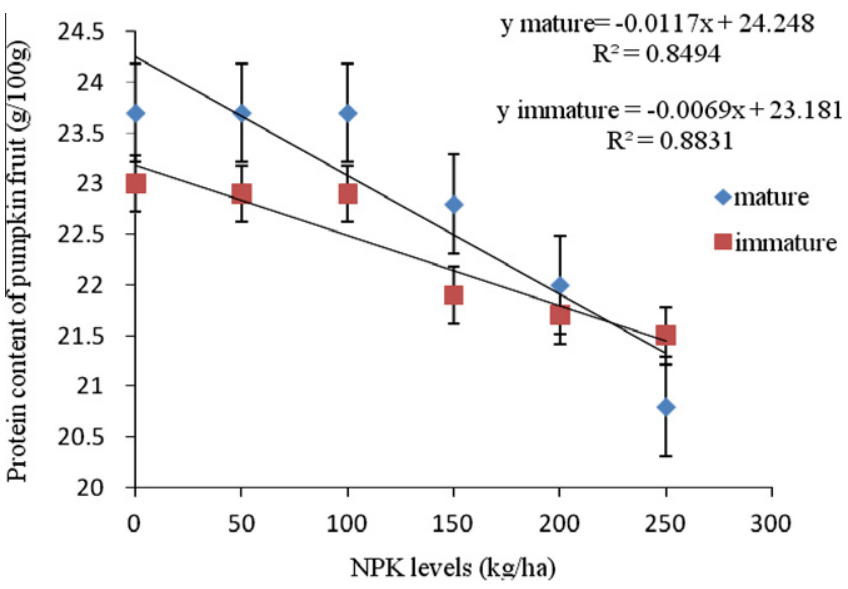

Fig. 1. Protein contents of pumpkin young and mature fruits (dry weight basis).

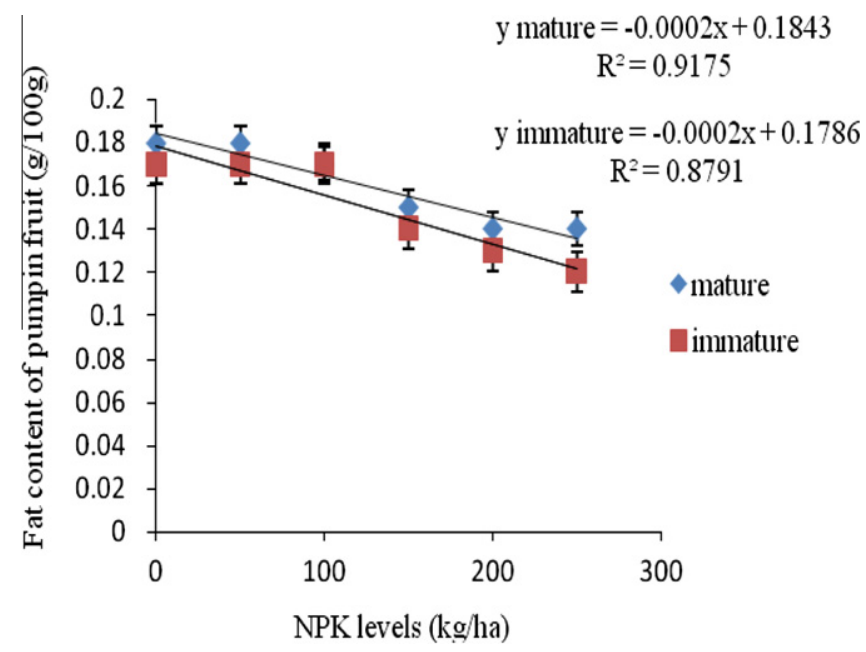

Fig. 2. Fat contents of pumpkin young and mature fruits (dry weight basis).

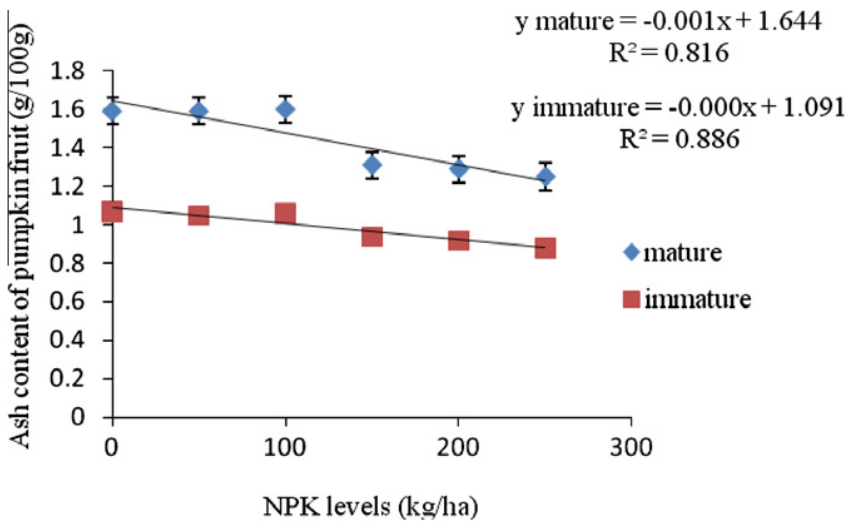

Fig. 3. Ash contents of pumpkin young and mature fruits (dry weight basis).

mature fruit across all the fertilizer levels (Fig. 3). The crude fibre of both young and mature fruits were not significantly different at $0-100 \mathrm{~kg} / \mathrm{ha}$ fertilizer application; however, at higher fertilizer level, crude fibre was significantly higher in the mature fruit (Fig. 4). The carbohydrate content of both young and mature fruits increased with increasing fertilizer application, but the mature fruit had significantly higher carbohydrate content at 0-100 and $250 \mathrm{~kg} /$ ha fertilizer rates (Fig. 5). 


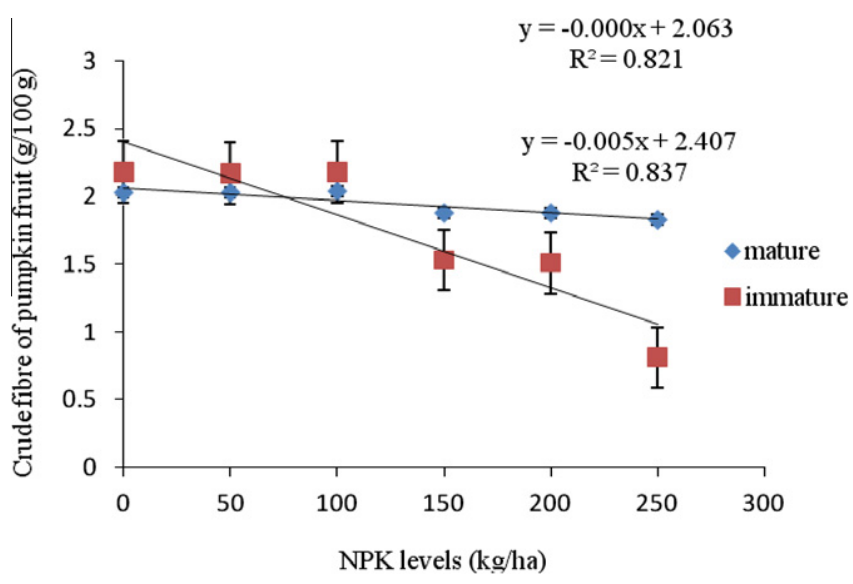

Fig. 4. Crude fibre contents of pumpkin young and mature fruits (dry weight basis).

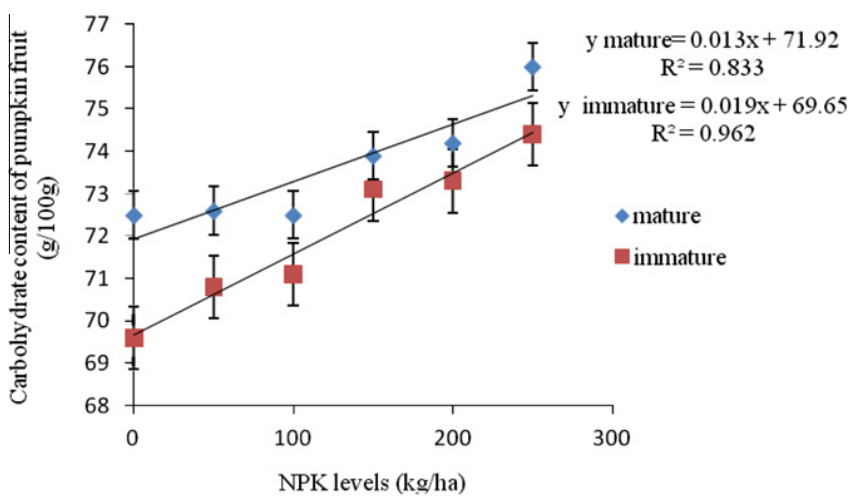

Fig. 5. Carbohydrate contents of pumpkin young and mature fruits (dry weight basis).

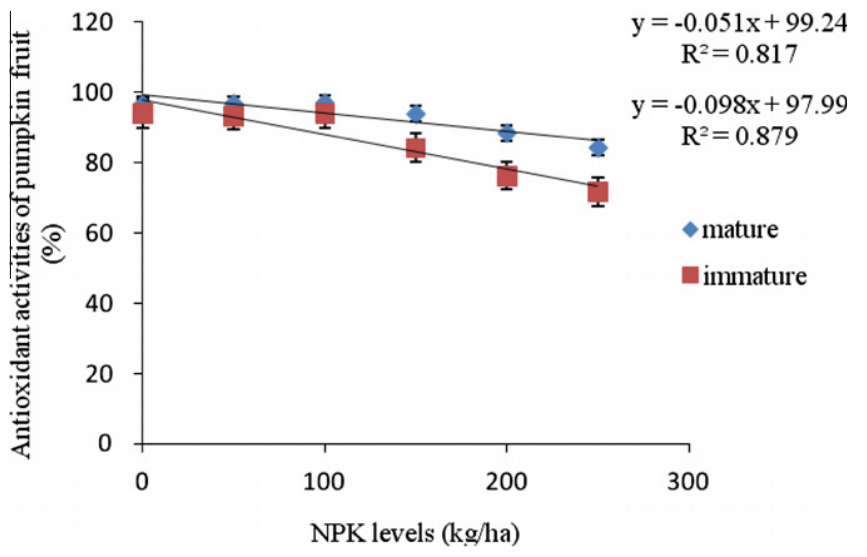

Fig. 6. Antioxidant activities of pumpkin young and mature fruits (dry weight basis).

Fig. 6 shows that antioxidant activities in pumpkin young and mature fruits were significantly influenced by fertilizer. Fertilizer influence showed consistent decrease in values of antioxidant activities as fertilizer rates increased. The control had significantly higher values than the values from the application of $150-250 \mathrm{~kg} /$ ha. The addition of 50 and $100 \mathrm{~kg}$ gave similar antioxidant activities with the zero fertilisation at 0.05 probability level, in both young and mature fruits. However, the antioxidant activities in the mature fruit were higher than those of young fruit, though not significantly different at $0-100 \mathrm{~kg} /$ ha fertilizer application.
Fertilizer influence showed consistent reduction in values of antioxidant phenolic compounds of both mature and young fruits as fertilizer rates increased. The control had a significantly higher values than the values from the application of $150-250 \mathrm{~kg} / \mathrm{ha}$. The addition of 50 and $100 \mathrm{~kg}$ gave similar phenol, flavonoid, anthocyanin and proanthocyanidin concentrations with the zero fertilisation at 0.05 probability level (Table 2). The concentration of total phenol in mature fruit is $71 \%$ higher than that in the young fruit. Flavonoid, anthocyanin and proanthocyanidin concentrations were $4.5 \%, 14 \%$ and $17 \%$ higher, respectively, in the mature fruit than in the young fruit (Table 1).

\section{Discussion}

The protein in immature and mature fruits was $23 \mathrm{~g} / 100 \mathrm{~g}$ while the carbohydrate content was $70 \%$ at $0-100 \mathrm{~kg}$ NPK/ha. This portion can supply more balanced nutrients than most vegetable crops, such as amaranth, with protein content (5.9/100 g), Celosia argentea (5.8/100 g), cowpea leaves (21/100 g), cabbage (1.6/ $100 \mathrm{~g})$, carrot $(1.0 / 100 \mathrm{~g})$, fluted pumpkin leaves $(4.3 / 100 \mathrm{~g})$, Celosia trygina (5.1/100 g) and Momordica balsamina (28/100 g) on a dry weight basis (FAO, 2010; Flyman \& Afolayan, 2007; Oloyede, Oloyede, Obuotor, \& Ibironke, 2011; Osagie \& Offiong, 1997). Its low cholesterol content makes it suitable as a diet for obese and hypertensive patients. The high protein content serves as a good supplement to cereals grains or as a meat substitute (Bressani, 1985; Matlhare et al., 1999) for poor rural communities. The antioxidant activities of pumpkin fruits analysed in this study ranged from $72 \%$ to $97 \%$, irrespective of the harvesting stages and fertilizer application levels. These values are above what Olajire, 2011 reported for some commonly consumed vegetables in Nigeria. However, the concentrations of the antioxidant phenolic compounds analysed were slightly lower.

The addition of fertilizer reduced the protein by $7 \%$, antioxidant activities by $24 \%$ and antioxidant phenolic compounds by $19-71 \%$. These reductions were due to the increasing $\mathrm{N}$ concentration in plants through fertilizer. The influence of $\mathrm{N}$ on protein concentration may be worse, when the concentration of essential nutrients in protein, which determines the quality of the fruits, is considered. The antioxidant components were reduced by $20-30 \%$ at fertilizer rates above $100 \mathrm{~kg} \mathrm{NPK} / \mathrm{ha}$. The result is similar to the reduction in total phenolics and antioxidant activities observed in asparagus (Paschold, Hermann, \& Artell, 1999) due to increased N fertilisation. At the University of Illinois, comparison was made of flavonoid content in tomatoes. Plants with limited $\mathrm{N}$ were shown to accumulate more flavonoids than those that are well supplied with inorganic fertilizers. It was concluded that synthetic fertilizers, in which $\mathrm{N}$ is easily accessible to the plant, may reduce the health benefits of tomatoes (Mitchell, \& Chassy, 2007). This agrees with the observation in this study that over fertilisation with $\mathrm{N}$ reduces nutrient quality and the health benefits of pumpkin fruits.

The proximate contents, the antioxidant activities and the concentrations of the antioxidant phenolic compounds obtained in pumpkin mature fruits were higher than those in the young fruit. Biologically active compounds have been found to increase in plant leaves during the process of maturation, depending on the different biosynthetic pathways and mechanisms of metabolic control (Bergquist, 2006; Khader \& Rama, 1998; Khader \& Rama, 2003; Lee \& Kader, 2000). However, according to Baranga (1983), the nutrient quality of plant leaves generally declines with advancing maturity, resulting in a decrease in protein levels and a concomitant increase in the amount of indigestible structural carbohydrates.

In conclusion, the mature fruit is better than the young fruit in terms of nutritional and antioxidant profiles while the fruit requires little or no NPK fertilizer for optimal nutritional values. 
Table 1

Antioxidant phenolic compounds in pumpkin fruits, as affected by NPK fertilizer (dry weight basis).

\begin{tabular}{|c|c|c|c|c|c|c|c|c|}
\hline \multirow{2}{*}{$\begin{array}{l}\text { Phenolic antioxidant } \\
\text { NPK level }\left(\mathrm{kg} \mathrm{ha}^{-1}\right)\end{array}$} & \multicolumn{2}{|c|}{ Total phenols (mg/100 g) } & \multicolumn{2}{|c|}{ Flavonoids (mg/100 g) } & \multicolumn{2}{|c|}{ Anthocyanins (mg/100 g) } & \multicolumn{2}{|c|}{ Proanthocyanidins (mg/100 g) } \\
\hline & Mature fruit & Immature fruit & Mature fruit & Immature fruit & Mature fruit & Immature fruit & Mature fruit & Immature fruit \\
\hline 0 & $33.5 a$ & $10.3 a$ & $6.01 \mathrm{a}$ & $5.44 a$ & $0.0220 \mathrm{a}$ & $0.016 a$ & $0.025 a$ & $0.021 \mathrm{a}$ \\
\hline 50 & $33.3 a$ & $10.2 \mathrm{a}$ & $5.95 a$ & $5.47 \mathrm{a}$ & $0.0220 \mathrm{a}$ & $0.016 a$ & $0.026 a$ & $0.021 \mathrm{a}$ \\
\hline 100 & $33.3 a$ & $10.4 a$ & $5.93 a$ & $5.46 a$ & $0.0220 \mathrm{a}$ & $0.016 a$ & $0.025 a$ & $0.021 \mathrm{a}$ \\
\hline 150 & $20.4 b$ & $7.71 b$ & $3.19 b$ & $3.74 b$ & $0.0098 b$ & $0.011 b$ & $0.015 b$ & $0.015 b$ \\
\hline 200 & $14.7 c$ & $6.65 c$ & $2.78 \mathrm{c}$ & $2.65 c$ & $0.0066 c$ & $0.009 c$ & $0.012 c$ & $0.008 \mathrm{c}$ \\
\hline 250 & $7.08 \mathrm{~d}$ & $4.94 \mathrm{~d}$ & $2.34 \mathrm{~d}$ & $2.51 \mathrm{~d}$ & $0.0050 \mathrm{~d}$ & $0.007 d$ & $0.005 d$ & $0.006 \mathrm{~d}$ \\
\hline
\end{tabular}

Means with the same letter in each column are not significantly different at $5 \%$ level of probability using Duncan's multiple range test.

Table 2

Antioxidant phenolic compounds in pumpkin young and mature fruits across the NPK levels (dry weight basis).

\begin{tabular}{|c|c|c|c|c|}
\hline Phenolic antioxidant & Total phenols (mg/100 g) & Flavonoids (mg/100 g) & Anthocyanins (mg/100 g) & Proanthocyanidins (mg/100 g) \\
\hline Mature fruit & 23.7 & 4.4 & 0.14 & 0.18 \\
\hline Immature fruit & 8.4 & 4.2 & 0.12 & 0.15 \\
\hline $\operatorname{LSD}(0.05)$ & 2.0 & NS & 0.004 & 0.008 \\
\hline
\end{tabular}

NS = not significant at $5 \%$ level of probability

\section{References}

Ames, B. N., Shigenaga, M. K., \& Hagen, T. M. (1993). Oxidants, antioxidants, and the degenerative diseases of aging. Proceedings of the National Academy of Sciences of the United States of America, 90, 7915-7922.

AOAC (1995). Official Methods of Analysis (15th ed.) Washington, DC. Association of. Official Agricultural Chemists, p. 1120

Baranga, D. (1983). Changes in chemical composition of food parts in the diet of Colobus Monkeys. Ecology, 64, 668-673.

Bergquist, S. (2006). Bioactive compounds in baby spinach (Spinacia oleracea L.): Effects of Pre- and Postharvest factors. Ph.D. Thesis, Swedish University of Agricultural Sciences, Alnarp.

Brand-Williams W., Cuvelier, M. E. and Berset, C. (1995). Use of a free radica method to evaluate antioxidant activity. LWT Food Science and Technology (28)1: 25-30.

Bressani, R. (1985). Nutritive value of cowpea. In S. R. Singh and K. O. Rachie (eds.). Cowpea research, production and utilization. John Wiley and Sons Ltd. Chichester.

Flyman M. V. and Afolayan A. J. (2007). Proximate and mineral composition of the leaves of Momordica balsamina L.: an underutilized wild vegetable in Botswana. International Journal of Food Sciences and Nutrition. 1-5, iFirst article.

Food and Agriculture Organization (FAO) (2010). Composition of Selected Foods from West Africa. Barbara S., Charrondiere U. R., Addy P., Samb B., Enujiugha V. N., Bayili R. G., Fagbohoun E. G., Smith I. F., Thiam I. and Burlingame B. (Editors).

Fuleki, T., \& Francis, F. J. (1968). Quantitative determination of anthocyanins 2. Determination of total anthocyanin and degradation index for cranberry juice. Journal of Food Science, 33, 78-83.

Guisti, M. M., \& Wrolstad, R. E. (2001). Characterization and measurement of anthocyanins by UV-Visible spectroscopy. Current Protocols in Food Analytical Chemistry, F1.2.1-F1.2.13.

Khader, V., \& Rama, S. (1998). Selected mineral content of common leafy vegetables consumed in India at different stages of maturity. Plant Foods for Human Nutrition, 53, 71-78.

Khader, V., \& Rama, S. (2003). Effect of maturity on macromineral content of selected leafy vegetables. Asia Pacific Journal of Clinical Nutrition, 12(1), 45-49.

Lamaison, J. L. C., \& Carnet, A. (1990). Teneurs en principaux flavonoides des fleurs de Crataegus monogyna Jacq et de Crataegus laevigata (Poiret D.C) en fonction de la vegetation. Pharmaceut Acta Helve, 65, 314-320.
Lee, S. K., \& Kader, A. A. (2000). Preharvest and postharvest factors influencing vitamin C content of horticultural crops. Postharvest Biology Techniques, 20 , 207-220.

Manjunath Prasad C. T., Ashok S. S., Vyakaranahal B. S., Nadaf H. L., and Hosamani R. M. (2008). Influence of nutrition and growth regulators on fruit, seed yield and quality of pumpkin cv. Arka Chandan. Karnataka J. Agric. Sci., 21(1): 115-117.

Matlhare T., Tshamekang E., Taylor F. W., Oagile O. and Modise D. M. (1999). Botswana. In: Chewa J. A., Eyzaguirre P., editors. The biodiversity of traditional leafy vegetables. Rome: International Plant Genetic Resources Institute. pp. 722.

Messiaen, C. M., \& Fagbayide, J. A. (2004). Cucurbita pepo linn. In G. J. H. Grubben \& O. A. Denton (Eds.), Plant resources of tropical Africa 2 Vegetables (pp. 273-277). Leiden, Netherlands/CTA, Wageningen, Netherlands: PROTA Foundation, Wageningen, Netherlands/Backhuys Publishers.

Mitchell, A.E., A. W. Chassy. Antioxidant and the nutritional quality of organic agriculture. 9 pages. <http://mitchell.ucdavis.edu/OrganicBetter.pdf >. (24 October 2007).

Olajire, A. A., \& Azeez (2011). Total antioxidant activity, phenolic, flavonoid and ascorbic acid contents of Nigerian vegetables. African Journal of Food Science and Technology, 2(2), 022-029.

Oloyede, F. M., Oloyede, F. A., Obuotor, E. M., \& Ibironke, S. I. (2011). Antioxidant activities and food value of five underutilized green leafy vegetables in south western Nigeria. Nigerian Journal of Nutritional Sciences, 32(1), 13-18.

Osagie A. U. and Offiong U. E. (1997). Nutritional Quality of Plant Foods. Published by the Postharvest Research unit, Department of Biochemistry, University of Benin, Benin City, Nigeria, pp. 1-277.

Paschold, P. J., Hermann, G., \& Artell, B. (1999). Nitrogen, yields, spear quality and Nmin residues of Asparagus. Gemuse Munchen, 35, 588-592.

Porter, L. J., Hristch, L. N., \& Chan, B. C. (1986). The conversion of procyanidins and prodelphinidins to cyanidins and delphinidins. Phytochemistry, 25, 225-230.

Rice-Evans, C., \& Miller, N. J. (1995). Antioxidants - The case for fruit and vegetables in the diet. British Food Journal, 97, 35-40.

Robinson, R. W., Decker-Walters, D. S. (1997). Cucurbits. Cab International Wallingford Oxon Ox 10 8DE, UK. pp. 1-206.

Singleton, V. L., \& Rossi, J. A. (1965). Colorimetry of total phenolics with phosphomolybdic phosphotungustic acid reagent. American Journal of Enology and Viticulture, 16, 144-158.

Version 9.1. SAS Institute Inc., Cary, NC. (2003). 